\title{
Luminous vibriosis in rock lobster Jasus verreauxi (Decapoda: Palinuridae) phyllosoma larvae associated with infection by Vibrio harveyi
}

\author{
B. K. Diggles ${ }^{1, *}$, G. A. Moss ${ }^{1}$, J. Carson ${ }^{2}$, C. D. Anderson ${ }^{3}$ \\ ${ }^{1}$ National Institute of Water and Atmospheric Research Ltd., PO Box 14-901, Kilbirnie, Wellington, New Zealand \\ ${ }^{2}$ Department of Primary Industries, Water \& Environment, PO Box 46, Kings Meadows, Launceston, Tasmania 7249, Australia \\ ${ }^{3}$ National Centre for Disease Investigation, Ministry for Agriculture and Forestry, PO Box 40742, Upper Hutt, New Zealand
}

\begin{abstract}
Studies were conducted to determine the cause of outbreaks of luminous vibriosis in phyllosoma larvae of the packhorse rock lobster Jasus verreauxi reared in an experimental culture facility. On 2 separate occasions mortalities of up to $75 \%$ over a period of 4 wk were observed in 4 th to 5th and 8th to 10 th instar phyllosomas at water temperatures of 20 and $23^{\circ} \mathrm{C}$, respectively. Affected larvae became opaque, exhibited small red spots throughout the body and pereiopods, and were faintly luminous when viewed in the dark. Histopathology showed that the gut and hepatopancreas tubules of moribund phyllosomas contained massive bacterial plaques. The hepatopancreas tubules of moribund larvae were atrophic and some contained necrotic cells sloughed into the lumen. Dense, pure cultures of a bacterium identified as Vibrio harveyi were isolated from moribund larvae. The disease syndrome was reproduced by in vivo challenge and $V$. harveyi was successfully reisolated from diseased larvae after apparently healthy larvae were exposed by immersion to baths of more than $10^{4} \mathrm{~V}$. harveyi $\mathrm{ml}^{-1}$ at $24^{\circ} \mathrm{C}$. Injured larvae were more susceptible to infection than were healthy larvae. Survival of larvae experimentally and naturally exposed to $V$. harveyi was improved when antibiotics were administered via bath exposures.
\end{abstract}

KEY WORDS: Spiny lobsters $\cdot$ Crustacea $\cdot$ Mariculture $\cdot$ Disease $\cdot$ Vibrio $\cdot$ New Zealand

\section{INTRODUCTION}

Disease management is important when maintaining lobsters in captivity (Fisher et al. 1978, Stewart 1980, 1984, Sindermann 1990). Diseases which have caused economic losses in captive clawed lobsters (Decapoda: Nephropidae) include bacterial infections, particularly shell disease and gaffkemia (Stewart 1984), fungi (Unestam 1973, Fisher et al. 1975, 1978), protozoa (Cawthorne et al. 1996), and nutritionally related diseases such as moult death syndrome (Bowser \& Rosemark 1981). In contrast, relatively few diseases have been reported to date from

*E-mail: b.diggles@niwa.cri.nz captive spiny lobsters (Decapoda: Palinuridae) (see Evans \& Brock 1994). The high commercial value of spiny lobsters has resulted in interest in their aquaculture (Booth \& Kittaka 1994). There may be considerable potential to increase spiny lobster production through rearing lobsters from eggs (Kittaka 1994, 1997, Kittaka et al. 1997) or growout of pueruli collected from the wild (Booth \& Kittaka 1994, Hooker et al. 1997). As the number of instances where spiny lobsters are held in captivity at high density increases, a concurrent increase in reports of their diseases may be expected. This paper reports the first record of Vibrio harveyi from cultured lobsters in New Zealand and describes 2 outbreaks of luminous vibriosis in phyllosoma larvae of the packhorse rock lobster Jasus verreauxi (Milne Edwards 1851). 


\section{MATERIALS AND METHODS}

Larval rearing. Phyllosomas of Jasus verreauxi were reared for over $100 \mathrm{~d}$ at $19^{\circ} \mathrm{C}$ in an upwelling tank system (Illingworth et al. 1997) at the Mahanga Bay Aquaculture Research Facility (Wellington, New Zealand) using partial seawater recirculation at $150 \%$ replacement $\mathrm{d}^{-1}$. Seawater was filtered through diatomaceous earth to $1 \mu \mathrm{m}$ and UV-irradiated. Tanks were maintained at light levels below $0.001 \mu \mathrm{mol} \mathrm{s}{ }^{-1} \mathrm{~m}^{-2}$ (Moss et al. 1999). Phyllosomas were fed 5 to $7 \mathrm{~d}$ old, 2 to $3 \mathrm{~mm}$ long brine shrimp Artemia salina and had reached instars 8 to 10 (Kittaka et al. 1997). The same methods were being used 12 mo later prior to a second disease outbreak in 4th to 5th instar phyllosomas, except the water temperature was maintained at $20^{\circ} \mathrm{C}$.

Bacteriology. During the original disease outbreak, 4 moribund Jasus verreauxi phyllosoma larvae exhibiting clinical signs of disease and 3 apparently healthy larvae were surface-disinfected by immersion in $70 \%$ ethanol for approximately $10 \mathrm{~s}$. The surfacesterilised larvae were held in flame-sterilised forceps and blotted on lint-free tissues to remove excess ethanol before being sagittally sectioned with flame sterilised microscissors. The cut surface of one side of each larva was used to inoculate plates of thiosulphate citrate bile salt sucrose agar (TCBS, Oxoid), and tryptic soy agar with $2 \% \mathrm{NaCl}(\mathrm{TSA}+2)$ (Gibco BRL) which were incubated at $20^{\circ} \mathrm{C}$ and examined daily for $7 \mathrm{~d}$. Bacteria isolates were subcultured to ensure purity before being stored in long-term preservation medium (Beuchat 1974) for up to $1 \mathrm{wk}$ prior to identification. Biochemical characterisation was undertaken by subjecting isolates to 52 phenotypic tests using methods described by Baumann et al. (1971), Furniss et al. (1978), and West \& Colwell (1984). Luminescence was assessed by growing bacteria on plates of Schneider \& Rheinheimmer's Medium (Austin \& Lee 1992) and incubating the cultures at $15^{\circ} \mathrm{C}$ for $24 \mathrm{~h}$. Plates were examined in total darkness for the presence of luminous colonies. Phenotypic data were compared to a probabilistic data matrix for Vibrio species (Bryant et al. 1986) using a regularly updated version of the Bacterial Identifier program (Bryant \& Smith 1991). An acceptable identification was reached when the identification score equaled or exceeded 0.98. Identical methods were used to identify bacteria isolated during the second disease outbreak.

Antimicrobial sensitivities. Minimum Inhibitory Concentration (MIC) tests were performed only on the Vibrio harveyi isolates obtained during the original disease outbreak. Tests for 14 antibiotics (SigmaAldrich), including oxolinic acid, oxytetracycline, chloramphenicol, trimethoprim, nitrofurantoin, furazolidone, neomycin, ampicillin, amoxycillin, co-trimazine (trimethoprim/sulphadiazine [1/5]), sulphadiazine, sul- phamethazine, streptomycin and trimethoprim/sulphamethazine (1/5), were based on the NCCLS microbroth dilution procedure as described by Carson \& Statham (1993). Stock concentrations of $0.1 \% \mathrm{w} / \mathrm{v}$, active ingredient, for each antibiotic were prepared using the solvents described by Anhalt \& Washington (1991) and diluted further with Mueller-Hinton broth (MHBS) (Oxoid) supplemented with $\mathrm{NaCl}$ to a final concentration of $1 \% \mathrm{w} / \mathrm{v}$. Doubling dilutions of the antibiotic in MHBS were prepared in sterile microtitre trays (Nunc) to give a range of final antibiotic concentrations between 25 and $0.02 \mu \mathrm{g} \mathrm{ml}^{-1}$. The broths were inoculated with $V$. harveyi harvested from an overnight plate culture and suspended in MHBS to a concentration equivalent to McFarland standard 0.5 as determined with a Hach 2001P Turbidimeter. The plates were incubated at $25^{\circ} \mathrm{C}$ for $24 \mathrm{~h}$ and MIC endpoints identified by visual inspection for the presence/absence of growth.

Histology. The unused halves of the sagittally sectioned phyllosoma larvae (4 moribund and 3 apparently healthy individuals) examined during the original disease outbreak were immediately fixed in $10 \%$ $(\mathrm{v} / \mathrm{v})$ formalin in seawater filtered to $0.22 \mu \mathrm{m}$. All samples were embedded in paraffin wax for sagittal sectioning $(6 \mu \mathrm{m})$ using standard histological procedures, stained with hematoxylin and eosin and examined using light microscopy.

Experimental infections. Trial 1: Bacteria used for experimental infection of healthy larvae were harvested from the edge of Vibrio harveyi colonies subcultured on TCBS at $20^{\circ} \mathrm{C}$ from isolates obtained from the original outbreak of luminous vibriosis. The bacteria were suspended in $10 \mathrm{ml}$ of seawater sterilised by filtration $(0.22 \mu \mathrm{m}$ pore size) and a 10 -fold dilution series in filter sterilised seawater was prepared from $10^{-1}$ to $10^{-3}$ in sterile $15 \mathrm{ml}$ centrifuge tubes. An estimate of the cell number in the original suspension was made by direct microscopic count of motile bacteria in the $10^{-3}$ dilution using a Reichert Brite-line Improved Neubauer hemocytometer. The mean of 5 replicate counts was used. Final concentrations used in the experimental beakers were prepared by adding appropriate volumes of a stock suspension of approximately $10^{8}$ bacteria $\mathrm{ml}^{-1} \mathrm{~V}$. harveyi. Groups of 5 apparently healthy Jasus verreauxi phyllosomas (instar 8 to 10) were placed in six 11 glass beakers in a $24^{\circ} \mathrm{C}$ water bath. Each beaker contained $400 \mathrm{ml}$ of UV-irradiated, filtered (1 $\mu \mathrm{m}$ pore size) seawater. The phyllosomas in Beakers A, B and C were exposed to $V$. harveyi at concentrations of $10^{4}, 10^{6}$, or $10^{7} \mathrm{~V}$. harveyi $\mathrm{ml}^{-1}$, respectively, by direct immersion (Table 1). The remaining 3 beakers ( $D, E$, and F) were negative controls and had no bacteria added. After $48 \mathrm{~h}$ the water in all beakers was diluted $50 \%$ by the addition of $400 \mathrm{ml}$ of filtered ( $1 \mu \mathrm{m}$ pore size) and UVirradiated seawater. The trial was terminated $7 \mathrm{~d}$ after 
Table 1. Details of experimental design and results of experimental challenges Trial 1 of healthy Jasus verreauxi larvae (8th to 10 th instar) exposed to Vibrio harveyi by bath immersion or via Artemia at $24^{\circ} \mathrm{C}$. - - no attempt made to reisolate bacteria from non-luminescent phyllosomas

\begin{tabular}{|lcccccc|}
\hline Beaker & $\begin{array}{c}\text { Bacterial } \\
\text { concentration }\left(\mathrm{ml}^{-1}\right)\end{array}$ & $\begin{array}{c}\text { Method of } \\
\text { exposure }\end{array}$ & $\begin{array}{c}\text { No. of } \\
\text { larvae }\end{array}$ & $\begin{array}{c}\text { Feeding } \\
\text { details }\end{array}$ & $\begin{array}{c}\text { \% survival } \\
\text { after 7 d }\end{array}$ & $\begin{array}{c}\text { V. harveyi } \\
\text { reisolated }\end{array}$ \\
\hline A & $10^{4}$ & Bath & 5 & Unfed & 40 & From 100\% of dead larvae \\
B & $10^{6}$ & Bath & 5 & Unfed & $80^{\text {a }}$ & - \\
C & $10^{7}$ & Bath & 5 & Unfed & 0 & From 100\% of dead larvae \\
D & 0 & Control & 5 & Unfed & 100 & - \\
E & 0 & Control & 5 & Fed Artemia & 100 & - \\
F & 0 & Control & 5 & Unfed & 100 & - \\
a 1 phyllosoma unaccounted for & & & & & \\
\hline
\end{tabular}

the initial challenge with V. harveyi. The number of dead or luminous phyllosomas was noted for each treatment. The phyllosomas in Beakers A, B, C, D and F were not fed during the experiment; however control phyllosomas in 1 beaker (Beaker E) were fed with Artemia to assess whether mortalities could be attributed to not feeding larvae for $7 \mathrm{~d}$ (Table 1). Water temperature remained at $24^{\circ} \mathrm{C}$ and salinity $35 \%$ throughout the experiment, which was conducted under a $24 \mathrm{~h}$ dark photoperiod. The water in all beakers was not aerated for the duration of this experiment.

Trial 2: A second experiment was performed $11 \mathrm{mo}$ after the original disease outbreak to determine if injured larvae were more susceptible to infection by Vibrio harveyi during bath exposures. Groups of 10 apparently healthy Jasus verreauxi phyllosomas (instar 4 to 5) were each placed in four 11 glass beakers containing $1000 \mathrm{ml}$ of filtered (1 $\mu \mathrm{m}$ pore size), UVirradiated seawater. All of the phyllosomas in Beakers $A$ and B had 2 pereiopods severed using flame sterilised microscissors, while all phyllosomas in Beakers $\mathrm{C}$ and $\mathrm{D}$ were left intact. Approximately $10^{7}$ colony forming units (CFU) of $V$. harveyi in $1 \mathrm{ml}$ of tryptic soya broth (TSB) (Oxoid) was then added to Beakers B and $\mathrm{D}$ to make a bath concentration of $10^{4} \mathrm{CFU} \mathrm{ml}{ }^{-1}$. The $V$. harveyi used in this experiment was recovered from 11 mo storage in long-term preservation medium and cultured for $24 \mathrm{~h}$ at $20^{\circ} \mathrm{C}$ in TSB. The number of $V$. harveyi CFU ml-1 of TSB used to inoculate beakers was determined using a 10-fold dilution series in TSB from $10^{-1}$ to $10^{-5}$. A $0.1 \mathrm{ml}$ aliquot of the $10^{-5}$ dilution was plated out on TSA +2 and colonies were counted after $18 \mathrm{~h}$ incubation at $20^{\circ} \mathrm{C}$. All beakers were examined daily and the trial was terminated $7 \mathrm{~d}$ after the initial challenge with $V$. harveyi. Water temperature remained at $22^{\circ} \mathrm{C}$ and salinity $35 \%$ throughout the experiment, which was conducted under a $24 \mathrm{~h}$ dark photoperiod. The water in all beakers was aerated and the phyllosomas were not fed for the duration of the experiment.

In vivo antibiotic trials. Trial 3: Groups of 5 apparently healthy Jasus verreauxi phyllosomas (instar 8 to 10) were placed in six 1 l glass beakers containing $400 \mathrm{ml}$ of filtered ( $1 \mu \mathrm{m}$ pore size), UV-irradiated seawater (Table 2 ) in a $24^{\circ} \mathrm{C}$ water bath. A bacterial suspension prepared as for Trial 1 was added to Beakers $\mathrm{B}, \mathrm{C}, \mathrm{D}, \mathrm{E}$ and $\mathrm{F}$ to achieve a concentration of $5 \times$ $10^{6}$ Vibrio harveyi $\mathrm{ml}^{-1}$. Twenty-four hours after introduction of the bacteria 4 antibiotic treatments, namely two 1:5 combinations of trimethoprim and sulphamethazine (Sigma-Aldrich) at 20:100 $\mathrm{mg} \mathrm{l}^{-1}$ and 10:50 $\mathrm{mg}$

Table 2. Details of experimental design and results for in vivo antibiotic Trial 3 on Jasus verreauxi larvae (8th to 10th instar) exposed by immersion to baths of $5 \times 10^{6}$ Vibrio harveyi $\mathrm{ml}^{-1}$ at $24^{\circ} \mathrm{C}$. -: no attempt made to reisolate bacteria from nonluminescent phyllosomas

\begin{tabular}{|c|c|c|c|c|c|}
\hline Beaker & $\begin{array}{l}\text { Bacterial } \\
\text { concentra } \\
\text { tion }\left(\mathrm{ml}^{-1}\right)\end{array}$ & $\begin{array}{l}\text { No. of } \\
\text { larvae }\end{array}$ & Antibiotic treatment $24 \mathrm{~h}$ post exposure & $\begin{array}{l}\% \text { survival } \\
\text { after } 7 \mathrm{~d}\end{array}$ & $\begin{array}{l}V . \text { harveyi } \\
\text { reisolated }\end{array}$ \\
\hline A & 0 & 5 & None, control & 100 & - \\
\hline $\mathrm{B}$ & $5 \times 10^{6}$ & 5 & None, control & 60 & $\mathrm{No}^{\mathrm{a}}$ \\
\hline $\mathrm{C}$ & $5 \times 10^{6}$ & 5 & $120 \mathrm{mg} \mathrm{l}^{-1}$ trimethoprim/sulphamethazine (1/5) & 100 & - \\
\hline $\mathrm{D}$ & $5 \times 10^{6}$ & 5 & $60 \mathrm{mg} \mathrm{l}^{-1}$ trimethoprim/sulphamethazine (1/5) & 80 & From $100 \%$ of dead larvae \\
\hline $\mathrm{E}$ & $5 \times 10^{6}$ & 5 & $0.1 \mathrm{mg} \mathrm{l}^{-1}$ nifurpirinol (prefuran) & 20 & From $100 \%$ of dead larvae \\
\hline $\mathrm{F}$ & $5 \times 10^{6}$ & 5 & $100 \mathrm{mg} \mathrm{l}^{-1}$ oxytetracycline hydrochloride & 80 & $\mathrm{No}^{\mathrm{b}}$ \\
\hline
\end{tabular}


$\mathrm{l}^{-1}$, nifurpirinol $\left(0.1 \mathrm{mg} \mathrm{l}^{-1}\right)$ (Argent laboratories) and oxytetracycline hydrochloride $\left(100 \mathrm{mg} \mathrm{l}^{-1}\right)$ (SigmaAldrich) were added to Beakers C, D, E and F, respectively (Table 2). Each antibiotic was dissolved separately in $100 \mathrm{ml}$ of filtered (1 $\mu \mathrm{m}$ pore size), UV-irradiated seawater at $24^{\circ} \mathrm{C}$ and added to its respective beaker, with the beaker volume being made up to $800 \mathrm{ml}$ with filtered and irradiated seawater. No antibiotics were added to Beakers A and B. Beaker A, which contained no bacteria or antibiotics, was used as a handling control, while Beaker B was used as a positive bacterial control. At the same time as antibiotics were introduced to Beakers $C, D, E$ and $F$, the volume of Beakers A and B was increased to $800 \mathrm{ml}$ by addition of $400 \mathrm{ml}$ of filtered (1 $\mu \mathrm{m}$ pore size), UV-irradiated seawater. All beakers were examined daily for an additional $7 \mathrm{~d}$. Artemia were added to all beakers as food on the Days 6 and 7 after addition of the antibiotics, and at the same time water changes of approximately $30 \%$ were performed. Water temperature remained at $24^{\circ} \mathrm{C}$ and salinity $35 \%$ o throughout the experiment, which was conducted under a $24 \mathrm{~h}$ dark photoperiod. The water in all beakers was not aerated for the duration of this experiment.

Trial 4: A year after the original disease outbreak a second in vivo antibiotic trial was performed on Jasus verreauxi phyllosomas (instar 4 to 5) which were obtained from an upwelling system $24 \mathrm{~h}$ after mortalities due to luminous vibriosis were first observed. Groups of $10 \mathrm{~J}$. verreauxi phyllosomas were each placed in sixteen $1 \mathrm{l}$ glass beakers containing $1000 \mathrm{ml}$ of filtered ( $1 \mu \mathrm{m}$ pore size), UV-irradiated seawater. Half of the beakers were incubated in a water bath at $16^{\circ} \mathrm{C}$ and the other half were incubated at $20^{\circ} \mathrm{C}$. The phyllosomas at each temperature were given either no treatment, or $10^{4} \mathrm{CFU} \mathrm{ml^{-1 }}$ Vibrio harveyi were added, $120 \mathrm{mg} \mathrm{l}^{-1}$ trimethoprim/sulphadimidine (1/5) added, or $10^{4} \mathrm{CFU} \mathrm{ml} \mathrm{V}$. harveyi $+120 \mathrm{mg} \mathrm{l}^{-1}$ trimethoprim/ sulphadimidine (1/5) added. Two replicate beakers were used for each treatment at each temperature. The number of $V$. harveyi $\mathrm{CFU} \mathrm{m}{ }^{-1}$ was determined as described for Trial 2. All beakers were examined daily and the trial was terminated after $7 \mathrm{~d}$. Salinity was $35 \%$ throughout the experiment, which was conducted under a $24 \mathrm{~h}$ dark photoperiod. The water in all beakers was aerated and the phyllosomas were not fed for the duration of this experiment.
Whenever dead phyllosomas were recorded in Trials 1 to 4 , they were surface sterilised in $70 \%$ ethanol and samples were collected for bacterial culture and identification as described previously. Furthermore, all surviving phyllosomas were examined for bacteriology at the termination of Trials 2 and 4.

Statistics. The significance of differences in survival of larvae between treatments at the termination of Trial 4 was analysed from data pooled from individual beakers from both 16 and $20^{\circ} \mathrm{C}$ by 1 -way analysis of variance using SigmaStat software (Jandel Scientific). Data were analysed for normality using the Kolmogorov-Smirnov test and differences between significant values were examined using the Student-Newman-Keuls method. Values of $p<0.05$ were considered significant.

\section{RESULTS}

\section{Onset of disease}

During the original disease outbreak mortalities began in an upwelling tank containing approximately 850 phyllosoma larvae (instars 8, 9 and 10), $3 \mathrm{~d}$ after the water temperature was raised from $19 \pm 1$ to $23^{\circ} \mathrm{C}$. Water temperature was reduced to $20^{\circ} \mathrm{C}$ immediately after the first mortalities were observed, but moderate mortalities (30 to 50 larvae $\mathrm{d}^{-1}$ ) continued. Luminous larvae were first noticed $6 \mathrm{~d}$ after the water temperature increase. Apparently healthy phyllosomas were active and transparent when viewed in natural light (Fig. 1). Affected larvae were lethargic, slightly opaque when viewed in natural light (Fig. 2), exhibited small red spots throughout the body and pereiopods, and were faintly luminous when viewed in the dark. Mortality levels remained elevated for $2 \mathrm{wk}$, declined, then spiked sporadically until around 1 mo after the temperature change. After $1 \mathrm{mo}$, less than 200 larvae survived, representing a loss of over $75 \%$ of larvae during the disease episode. A second outbreak of luminous vibriosis occurred in the 4 th to 5 th instar phyllosomas around 12 mo after the original disease outbreak. This outbreak occurred at $20^{\circ} \mathrm{C}$ and did not follow an increase in water temperature. Clinical signs of disease and mortality rates were virtually identical to those observed during the original disease outbreak.

Figs. 1 to 4. Jasus verreauxi. Fig. 1. Gross appearance of the digestive gland of an apparently healthy phyllosoma viewed with transmitted light showing transparent appearance of tubules (arrows) which contain food material. Scale bar $=200 \mu \mathrm{m}$. Fig. 2. Gross appearance of the digestive gland of a luminous phyllosoma infected with Vibrio harveyi. Note opaque appearance

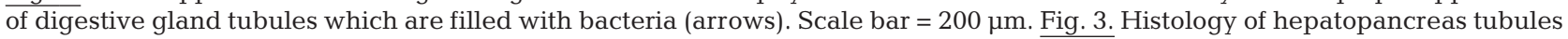
of an apparently healthy phyllosoma. C: cuticle, arrows = connective tissue. Scale bar $=25 \mu \mathrm{m}$. Fig. 4. Histology of gut of a luminous phyllosoma. Note massive bacterial plaque (B), necrosis (arrows) and infiltrating haemocytes (arrowheads). Scale bar $=65 \mu \mathrm{m}$ 

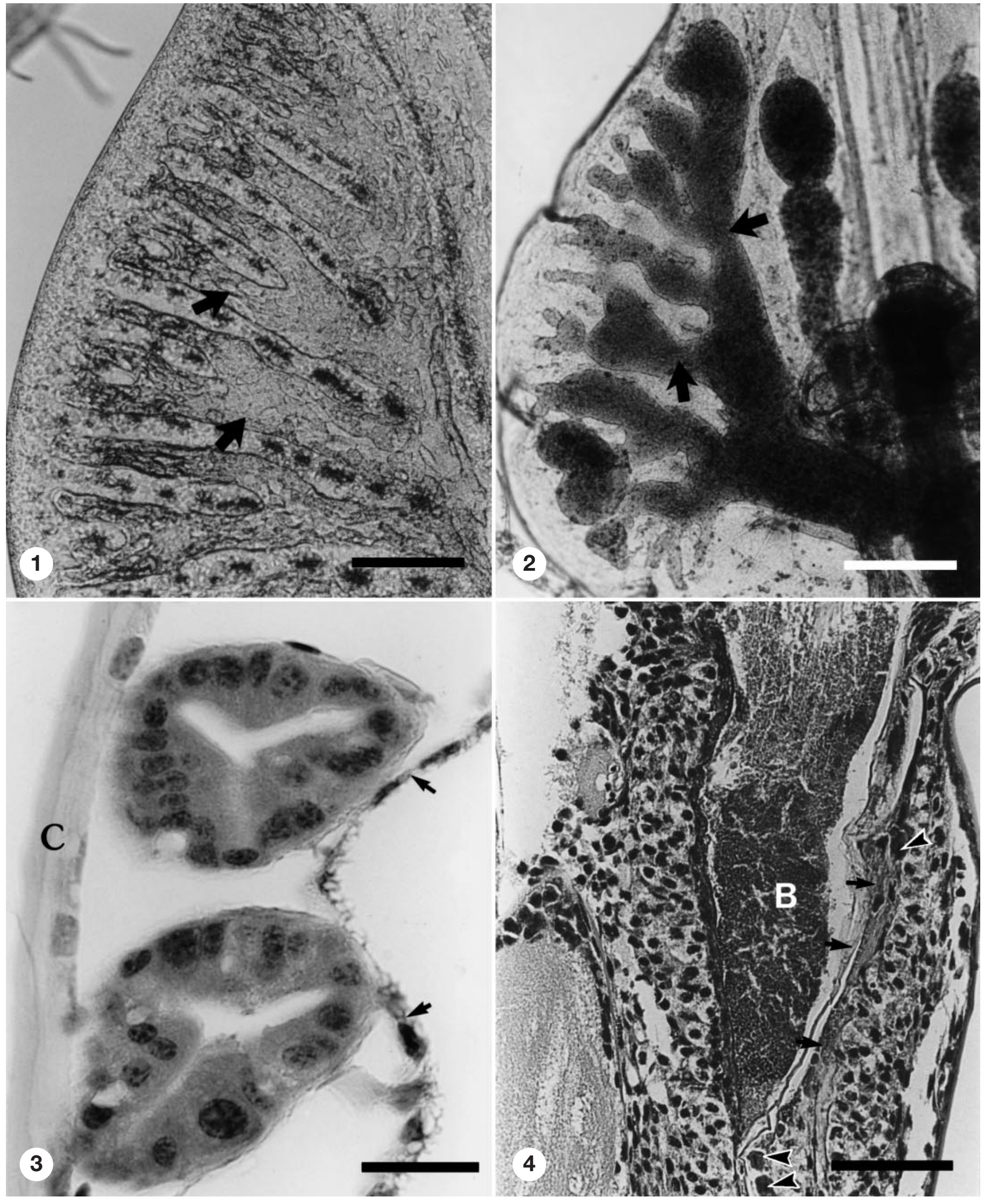


\section{Bacteriology}

Heavy growth of a sucrose-negative (green coloured on TCBS) bacterium was isolated in pure culture on both TCBS and TSA+ 2 from 3 out of 4 of the moribund phyllosomas sampled during the original disease outbreak. No bacteria were isolated from the fourth mori-

Table 3. Biochemical characteristics of bacteria isolated from Jasus verreauxi larvae during the original disease outbreak. +: positive reaction, -: negative reaction, cs: carbon source, NT: not tested

\begin{tabular}{|c|c|c|}
\hline Test & V. harveyi & Vibrio sp. \\
\hline Swarming & - & - \\
\hline Growth in $0 \% \mathrm{NaCl}$ & - & - \\
\hline Thornley's arginine dihydrolase & - & - \\
\hline Moller's lysine decarboxylase & + & - \\
\hline Moller's ornithine decarboxylase & + & - \\
\hline Nitrate reduction & + & - \\
\hline Oxidase & + & + \\
\hline Indole & + & + \\
\hline ONPG & + & - \\
\hline Voges proskauer reaction & - & - \\
\hline Resistance to $\mathrm{O} 12910 \mu \mathrm{g} \mathrm{ml}^{-1}$ & - & - \\
\hline Resistance to O129 $150 \mu \mathrm{g} \mathrm{ml}^{-1}$ & - & - \\
\hline Resistance to ampicillin $(10 \mu \mathrm{g})$ & + & + \\
\hline Resistance to polymyxin B (50 i.u.) & - & - \\
\hline Resistance to tellurite $(0.0005 \%)$ & - & - \\
\hline Aesculin hydrolysis & + & - \\
\hline Alginase & + & + \\
\hline Urease & + & - \\
\hline Luminescence & + & NT \\
\hline L-arabinose acid & - & - \\
\hline Arbutin acid & + & - \\
\hline Mannose acid & + & + \\
\hline Salicin acid & + & - \\
\hline Sorbitol acid & - & - \\
\hline Sucrose acid & - & + \\
\hline Mannitol acid & + & + \\
\hline L-arabinose cs & - & + \\
\hline Cellobiose cs & + & - \\
\hline D-galactose cs & + & - \\
\hline D-glucose Cs & + & + \\
\hline D-mannose cs & + & - \\
\hline Melibiose cs & - & + \\
\hline Lactose cs & - & + \\
\hline Melizitose cs & - & + \\
\hline Sucrose cs & - & + \\
\hline Trehalose cs & + & + \\
\hline Xylose cs & - & + \\
\hline Ethanol cs & - & + \\
\hline Glycerol cs & + & + \\
\hline 1-propanol cs & - & - \\
\hline D-sorbitol Cs & - & - \\
\hline Gluconate cs & + & + \\
\hline D-glucuronate cs & + & + \\
\hline Amygdalin cs & + & + \\
\hline Arbutin Cs & + & + \\
\hline L-citrulline cs & - & + \\
\hline L-hydroxy proline cs & - & + \\
\hline L-leucine cs & + & + \\
\hline D-glucosamine cs & + & + \\
\hline DL-3-hydroxybutyrate cs & - & + \\
\hline a-ketoglutarate cs & + & + \\
\hline Succinate cs & + & + \\
\hline
\end{tabular}

bund phyllosoma or from 2 of 3 apparently healthy larvae. A mixed culture of sucrose-positive colonies (yellow on TCBS) and sucrose-negative colonies was isolated from the third apparently healthy larva. All isolates obtained from moribund phyllosomas and the sucrose negative isolate from the apparently healthy phyllosoma were phenotypically identical (Table 3) and were identified unequivocally as Vibrio harveyi with an identification score of 0.98 . These isolates gave atypical results for resistance to $\mathrm{O} / 12910 \mu \mathrm{g}$, alginase production, and utilisation of amygdalin, arbutin, L-leucine and D-glucosamine as sole carbon sources (Table 4). The remaining bacterium isolated in mixed culture from the apparently healthy phyllosoma was identified as a member of the genus Vibrio, but could not be identified to species (Table 3) and was not considered significant. The isolates are encoded under the Tasmania Department of Primary Industries, Water and Environment Fish Health Unit accession number 99/1052. Bacteria isolated from moribund larvae during the second outbreak of luminous vibriosis were again identified as $V$. harveyi; however, 4 of the 5 isolates examined during the second disease outbreak exhibited minor differences in their biochemical profiles compared to the original isolate. Test results which varied between these isolates included resistance to $10 \mu \mathrm{g}$ of the vibriostatic agent O/129 (4 isolates), alginase negative (3 isolates), non-luminescent ( 2 isolates), acid production from sucrose ( 2 isolates), no acid production from mannitol (1 isolate), utilisation of sucrose (2 isolates), L-citrulline (1 isolate), and D-glucosamine ( 1 isolate) and inability to use L-leucine ( 3 isolates), amygdalin (3 isolates), D-glucuronate (2 isolates), and arbutin (2 isolates) as sole carbon sources.

\section{Antimicrobial sensitivities}

In vitro tests found the Vibrio harveyi isolated during the original disease outbreak was most sensitive to oxolinic acid, with a MIC of $0.2 \mu \mathrm{g} \mathrm{ml}^{-1}$, oxytetracy-

Table 4. Atypical phenotypic test results for isolates of Vibrio harveyi from Jasus verreauxi larvae during the original disease outbreak. cs: sole carbon source test

\begin{tabular}{|lcc|}
\hline Test & $\begin{array}{c}\text { Recorded } \\
\text { result }\end{array}$ & $\begin{array}{c}\text { \% of strains positive } \\
\text { for characteristic }^{\mathrm{a}}\end{array}$ \\
\hline O/129 10 $\mu \mathrm{g}$ resistance & - & 71 \\
Alginase & + & 38 \\
Amygdalin cs & + & 8 \\
Arbutin cs & + & 33 \\
L-leucine cs & + & 1 \\
D-glucosamine cs & + & 4 \\
a51 $V$. harveyi strains in database & \\
\hline
\end{tabular}


cline (MIC $0.78 \mathrm{\mu g} \mathrm{ml}^{-1}$ ) and chloramphenicol (MIC $1.56 \mathrm{\mu g} \mathrm{ml}^{-1}$ ) (Table 5). The MIC for trimethoprim and nitrofurantoin was $6.25 \mu \mathrm{g} \mathrm{ml}^{-1}$. The sensitivity to furazolidone and neomycin was considered equivocal (both $12.5 \mu \mathrm{g} \mathrm{ml}^{-1}$ ), and varying levels of resistance (based on likely achievable antibiotic concentrations in treated larvae) were assumed for ampicillin, amoxycillin, co-trimazine, sulphadiazine, sulphamethazine, streptomycin and trimethoprim/sulphamethazine (MIC for all $>25 \mu \mathrm{g} \mathrm{ml}^{-1}$ ).

\section{Histology}

Apparently healthy phyllosomas had no bacteria evident in the lumen of hepatopancreas tubules (Figs. 1 \& 3), gut or hemolymph. The hepatopancreas tubules of apparently healthy larvae were well organised and the hepatopancreocytes and connective tissue appeared normal (Fig. 3). The gut of luminous phyllosomas contained masses of bacteria, and foci of necrosis with evidence of hemocyte aggregation near necrotic areas (Figs. 2 \& 4). Most of the hepatopancreas tubules of moribund larvae were atrophic with necrosis of hepatopancreatocytes, and most contained bacteria in the lumen (Figs. $5 \& 6$ ). The hemal space under the carapace of moribund larvae contained areas of eosinophillic hemolymph containing low numbers of bacteria (Fig. 5). Sloughing of necrotic hepatopancreatocytes into the lumen of hepatopancreas tubules was also noted (Fig. 7).

\section{Experimental infections}

Trial 1

Survival in Beaker A after 7 d was $40 \%$ and Vibrio harveyi was reisolated from all 3 of the larvae that died (Table 1). All of the phyllosomas in beaker $\mathrm{C}\left(10^{7} \mathrm{~V}\right.$. harveyi $\mathrm{ml}^{-1}$ bath) had died by $3 \mathrm{~d}$ post exposure (PE) and $V$. harveyi was reisolated from all dead larvae. In contrast none of the phyllosomas in Beaker B $\left(10^{6} \mathrm{~V}\right.$. harveyi $\mathrm{ml}^{-1}$ bath) were luminous after $7 \mathrm{~d}_{\text {i however, }}$ 1 phyllosoma was unaccounted for and may have been cannibalised (Table 1). Both fed and unfed control larvae had $100 \%$ survival after $7 \mathrm{~d}$ (Table 1).

\section{Trial 2}

Mortalities were first recorded $2 \mathrm{~d}$ PE, when 2 dead and luminous phyllosomas were removed from Beaker D (Fig. 8). Mortalities were first observed in Beakers $\mathrm{A}$ and $\mathrm{B}$ at $3 \mathrm{~d} \mathrm{PE}$. When the experiment was terminated after $7 \mathrm{~d} \mathrm{PE}$, survival was $35 \%$ in the dam-
Table 5. Results of in vitro antibiotic minimum inhibitory concentration assays for Vibrio harveyi isolated from Jasus verreauxi larvae during the original disease outbreak. S: sensitivity; E: equivocal; R: resistant

\begin{tabular}{|lcc|}
\hline Antibiotic & $\begin{array}{c}\text { Minimum inhibitory } \\
\text { concentration }\left(\mu \mathrm{g} \mathrm{ml}^{-1}\right)\end{array}$ & Result $^{\mathrm{a}}$ \\
\hline Oxolinic acid & 0.2 & $\mathrm{~S}$ \\
Oxytetracycline & 0.78 & $\mathrm{~S}$ \\
Chloramphenicol & 1.56 & $\mathrm{~S}$ \\
Trimethoprim & 6.25 & $\mathrm{~S}$ \\
Nitrofurantoin & 6.25 & $\mathrm{~S}$ \\
Furazolidone & 12.5 & $\mathrm{E}$ \\
Neomycin & 12.5 & $\mathrm{R}$ \\
Ampicillin & $>25$ & $\mathrm{R}$ \\
Amoxycillin & $>25$ & $\mathrm{R}$ \\
Co-trimazine (1/5) & $>25$ & $\mathrm{R}$ \\
Sulphadiazine & $>25$ & $\mathrm{R}$ \\
Sulphamethazine & $>25$ & $\mathrm{R}$ \\
Streptomycin & $>25$ & \\
Trimethoprim + & $>25$ & \\
Sulphamethazine (1/5) & & \\
a Based on likely achievable antibiotic concentration in \\
treated larvae & & \\
\hline
\end{tabular}

aged larvae (pooled from Beakers A [40\% survival] and B [30\% survival]), and $50 \%$ in the undamaged larvae exposed to Vibrio harveyi in Beaker D. Survival of undamaged, unexposed phyllosomas in Beaker C was $100 \%$ (Fig. 8). Pure cultures of V. harveyi were reisolated from all of the phyllosomas that died during this experiment. When bacteriology was performed on the phyllosomas which survived $7 \mathrm{~d}$, the only bacteria isolated were light growths of pure $V$. harveyi recovered only from 2 of the survivors in Beaker A, and from 1 of the survivors in Beaker D.

\section{In vivo antibiotic trials}

\section{Trial 3}

Two of the 5 control phyllosomas exposed to a bath of $5 \times 10^{6}$ Vibrio harveyi $\mathrm{ml}^{-1}$ had died by Day $7 \mathrm{PE}$ (Table 2); however, no V. harveyi were reisolated from these individuals. The survival of phyllosomas exposed to the $50: 10 \mathrm{mg} \mathrm{l}^{-1}$ combination of sulphamethazine and trimethoprim (Beaker D) and $100 \mathrm{mg} \mathrm{l}^{-1}$ oxytetracycline (Beaker F) was $80 \%$. One phyllosoma died in Beaker D after $5 \mathrm{~d}$ PE and V. harveyi was reisolated from this individual. The phyllosoma which died in Beaker $\mathrm{F}$ was found dead after $7 \mathrm{~d} \mathrm{PE}$, and showed signs of deformity in a moult. $V$. harveyi was not reisolated from this individual. Only 1 of the phyllosomas exposed to $0.1 \mathrm{mg} \mathrm{l}^{-1}$ Nifurpirinol in Beaker E survived. All dead phyllosomas in Beaker E were luminous and $V$. harveyi was reisolated from all of these larvae. No 

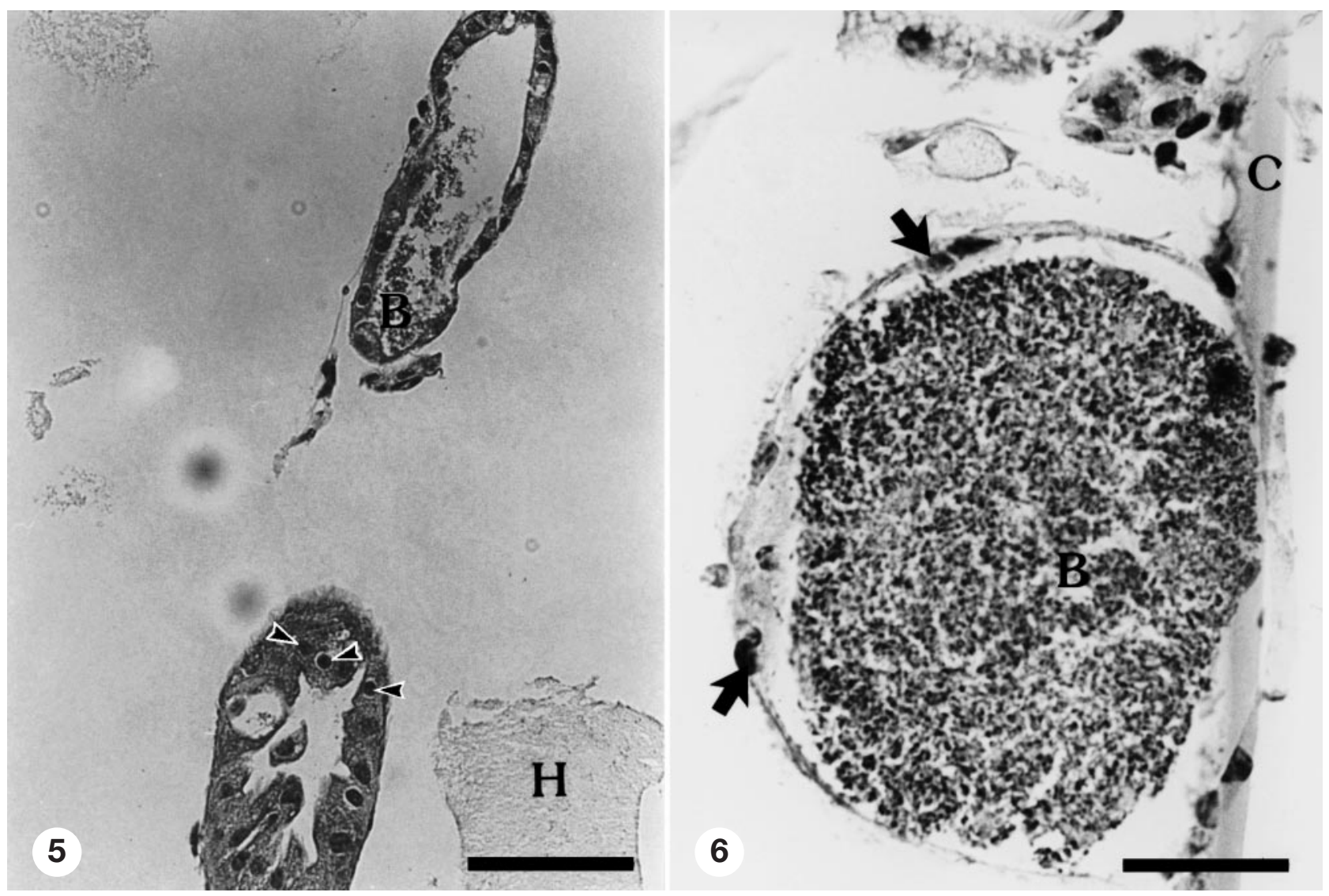

Figs. 5 \& 6. Jasus verreauxi. Fig. 5. Two adjacent hepatopancreas tubules of a luminous phyllosoma. The lower tubule contains necrotic hepatopancreocytes with pyknotic nuclei (arrowheads) while the upper tubule is atrophic with necrotic hepatopancreocytes and numerous bacteria (B) in the lumen. Note also scattered bacteria in hemolymph (H). Scale bar $=65 \mu \mathrm{m}$. Fig. 6 . Higher magnification of a hepatopancreas tubule of a luminous phyllosoma. Note complete atrophy and necrosis of hepatopancreocytes (arrows) and the lumen is packed with bacteria (B). C = cuticle. Scale bar $=25 \mu \mathrm{m}$

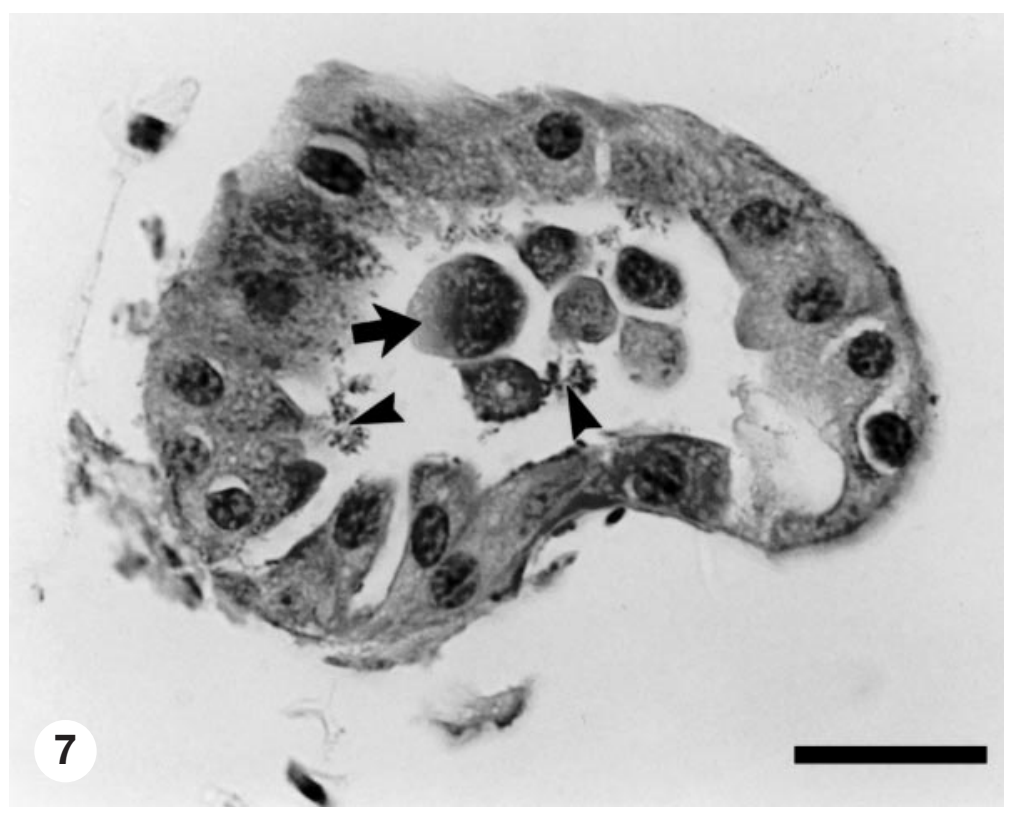

phyllosomas exhibited clinical signs of $V$. harveyi infection and survival was $100 \%$ in Beakers A (control, no bacteria) and C (20/100 $\mathrm{mg} \mathrm{l}^{-1}$ combination of trimethoprim/sulphamethazine).

Trial 4

Mortalities were recorded after $48 \mathrm{~h}$ for the phyllosomas exposed to $10^{4}$ Vibrio harveyi $\mathrm{ml}^{-1}$ at both 16 and $20^{\circ} \mathrm{C}$, and after $7 \mathrm{~d}$ their survival rates at these temperatures were 10 and $30 \%$, respectively

Fig. 7. Jasus verreauxi. A hepatopancreas tubule of a luminous phyllosoma. Note necrotic hepatopancreocytes (arrow) and bacteria (arrowheads) in the lumen. Scale bar $=25 \mu \mathrm{m}$ 


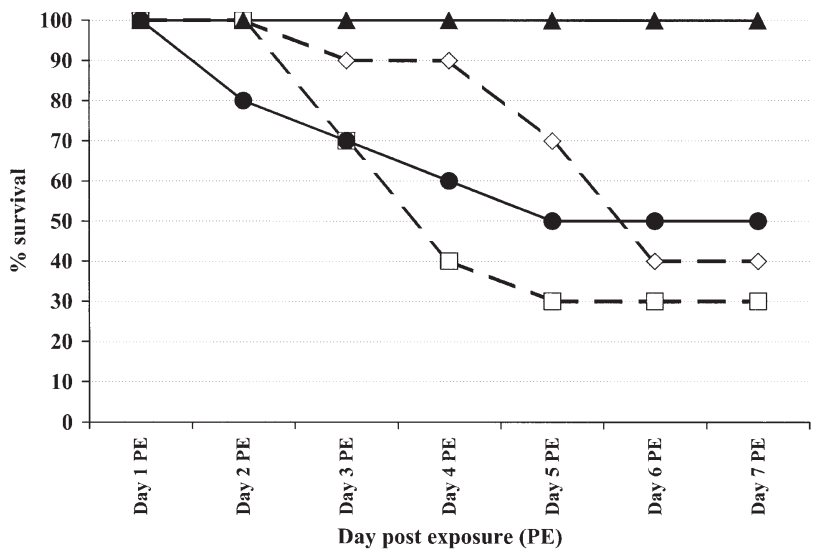

Fig. 8. Survival of damaged and undamaged phyllosoma larvae of Jasus verreauxi (4to to 5th instar) in Trial 2 at $22^{\circ} \mathrm{C}$. $(\multimap)$ Beaker A, injured, no Vibrio harveyi added; ( $\square-)$ Beaker $\mathrm{B}$, injured, $10^{4} \mathrm{CFU} \mathrm{ml}^{-1} V$. harveyi added; $(\rightarrow-)$ Beaker C, not injured, no V. harveyi added; (- - ) Beaker D, not injured, $10^{4} \mathrm{CFU} \mathrm{ml}{ }^{-1} V$. harveyi added

(Fig. 9). The survival rate of larvae exposed to $10^{4} \mathrm{~V}$. harveyi $\mathrm{ml}^{-1}$ was significantly lower $(\mathrm{p}=0.0002)$ than the survival of larvae from all other treatments. Only 65 and $50 \%$ of untreated larvae had survived after $7 \mathrm{~d}$ at 16 and $20^{\circ} \mathrm{C}$, respectively. Survival of larvae given $120 \mathrm{mg} \mathrm{l}^{-1}$ trimethoprim/sulphadimidine $(1 / 5)+10^{4}$ $V$. harveyi $\mathrm{ml}^{-1}$ after $7 \mathrm{~d}$ at 16 and $20^{\circ} \mathrm{C}$ was 80 and $70 \%$, respectively, and was not significantly different to survival of untreated larvae ( $p>0.05)$. Only 2 mortalities were recorded in larvae exposed to $120 \mathrm{mg} \mathrm{l}^{-1}$ trimethoprim/sulphadimidine (1/5), giving a survival rate after $7 \mathrm{~d}$ of $95 \%$ at both 16 and $20^{\circ} \mathrm{C}$ (Fig. 9), which was significantly higher than that of untreated larvae $(p<0.05)$, but not significantly different $(p>0.05)$ from survival of larvae given $120 \mathrm{mg} \mathrm{l}^{-1}$ trimethoprim/sulphadimidine $(1 / 5)+10^{4} \mathrm{~V}$. harveyi $\mathrm{ml}^{-1}$. Pure cultures of $V$. harveyi were recovered from all larvae that died during this experiment, and no bacteria were isolated from surviving larvae.

\section{DISCUSSION}

These outbreaks of disease in Jasus verreauxi phyllosoma larvae were associated with the presence of the luminous bacterium Vibrio harveyi and were the first records of luminous vibriosis in phyllosoma larvae of spiny lobsters. The original outbreak of luminous vibriosis followed an increase in water temperature from 19 to $23^{\circ} \mathrm{C}$, which is consistent with $V$. harveyi acting as a pathogen of crustaceans at warmer water temperatures $\left(>22^{\circ} \mathrm{C}\right)$. However, the second disease outbreak showed that luminous vibriosis could occur at $20^{\circ} \mathrm{C}$ without an increase in water temperature and further experiments reproduced the disease in the 4 th to 5th instar phyllosomas at water temperatures as low as $16^{\circ} \mathrm{C}$.

It has been established that epizootics of luminous vibriosis in penaeid shrimp larvae are associated with elevated numbers of luminous bacteria in growout ponds (Lavilla-Pitogo et al. 1998). Our experimental bath exposures with this Vibrio harveyi isolate demonstrated that it was possible to infect Jasus verreauxi phyllosomas via immersion in water containing $\geq 10^{4} \mathrm{~V}$. harveyi $\mathrm{ml}^{-1}$ and produce mortality rates approximating those observed in the disease outbreaks. We also observed phyllosomas with clinical signs of luminous vibriosis being cannibalised by apparently healthy phyllosomas, which themselves subsequently became luminous and moribund. This suggests that $V$. harveyi infections can also be transmitted via infected food, a suggestion supported by histopathology indicating that the digestive tract is the main target organ.

Inadvertent injury to the phyllosomas is a variable that may account for some of the inconsistencies we observed with our attempts to experimentally infect phyllosomas. Our data indicated that injured phyllosomas were more susceptible to infection, and it is possible that some larvae were accidentally injured while being transferred into experimental beakers, thus increasing the chances of infection in some beakers. Once injured phyllosomas became infected, bacteria appeared to rapidly proliferate internally, and the phyllosomas became luminous. The luminous phyllosomas then appeared to provide a source of virulent bacteria which increased the likelihood of infecting the

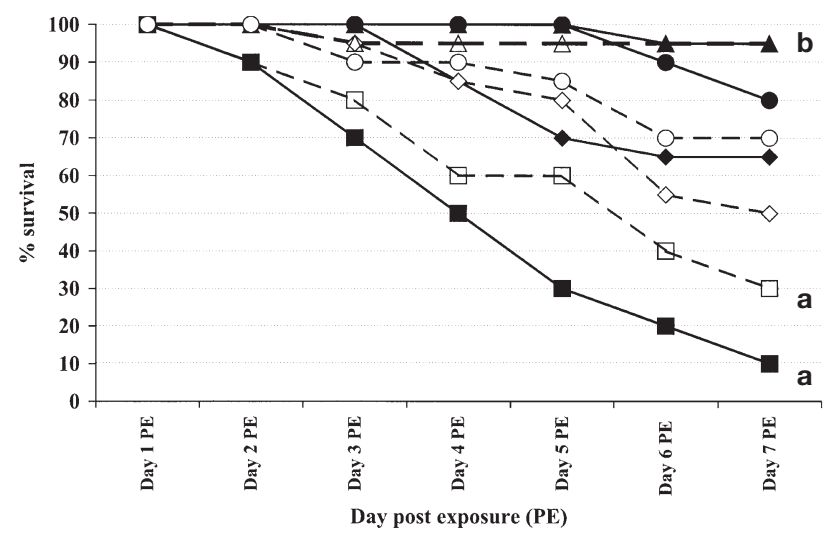

Fig. 9. Survival of phyllosoma larvae of Jasus verreauxi (4th to 5th instar) in Trial 4 during a Vibrio harveyi disease outbreak

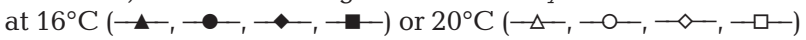
when given either no treatment $(\diamond$ or $\diamond), 10^{4} \mathrm{CFU} \mathrm{m} l^{-1} \mathrm{~V}$. harveyi (घ or ㅁ), $120 \mathrm{mg} \mathrm{l}^{-1}$ sulphadimidine/trimethoprim $(\boldsymbol{\Delta}$ or $\Delta)$, or $10^{4} \mathrm{CFU} \mathrm{ml^{-1 }} \mathrm{V}$. harveyi and $120 \mathrm{mg} \mathrm{l}^{-1}$ sulphadimidine/ trimethoprim $(\bullet$ or $\circ)$. a: significantly lower survival than all other treatments, b: significantly higher survival than untreated larvae 
remaining phyllosomas in the treatment (within the limited duration of the $7 \mathrm{~d}$ trial period) through cannibalism or decomposition. This may explain why mortalities were observed in Trial 1 at $10^{4}$ Vibrio harveyi $\mathrm{ml}^{-1}$, but not at $10^{6} V$. harveyi $\mathrm{ml}^{-1}$.

The recovery of Vibrio harveyi from dead and surviving larvae in Beaker A in Trial 2, where no V. harveyi was added, suggests that the bacterium may have been introduced into these beakers with apparently healthy larvae either externally (as larvae were not surface sterilised before being transferred to experimental beakers) or internally. Bacteriology results from non-luminous, apparently healthy larvae examined during the original disease outbreak showed that these could still carry low level $V$. harveyi in their internal organs. Since it is not known how many of the apparently healthy larvae used in experimental infections may have been asymptomatic carriers of $V$. harveyi infections, the results of our experimental infections cannot be strictly regarded as fulfilling Koch's postulates. However, repeated isolation of pure cultures of $V$. harveyi from luminous larvae in 2 disease outbreaks examined $1 \mathrm{yr}$ apart, and also from luminous larvae in our experimental infections, indicates that this bacterium is an important opportunistic pathogen of phyllosoma larvae of Jasus verreauxi under certain conditions, particularly when larvae are injured. Another inconsistency which occurred on more than one occasion was that $V$. harveyi was not reisolated from larvae that died exhibiting clinical signs of infection. This may have been due to ethanol contamination during inoculation of culture plates.

The results of the experiments conducted in the present study indicated that antibiotics could be used to significantly improve the survival of larvae during outbreaks of luminous vibriosis in phyllosoma cultures. Our MIC data suggest the efficacy of the trimethoprim/ sulphamethazine (1/5) and trimethoprim/sulphadimidine (1/5) treatments at $120 \mathrm{mg} \mathrm{l}^{-1}$ was probably due to the $20 \mathrm{mg} \mathrm{l}^{-1}$ of trimethoprim, which was over 3 times the MIC for this antibiotic. Furthermore, oxytetracycline (MIC $0.78 \mathrm{mg} \mathrm{l}^{-1}$ ) may have provided protection at much lower doses than the $100 \mathrm{mg} \mathrm{l}^{-1}$ used here, which might avoid the problems observed with deformities of larvae. However, Baticados et al. (1990) suggested that problems with antimicrobial drug-induced deformities in larval Penaeus monodon, together with the potential for development of antibiotic resistant strains of Vibrio harveyi (see Baticados et al. 1990, Karunasagar et al. 1994, Pillai \& Jayabalan 1996) were the main reasons why prophylactic use of antimicrobials should be discouraged in penaeid shrimp culture. We consider that these problems associated with antibiotic use are just as relevant for larviculture of spiny lobsters as they are for penaeid shrimp culture.
It is recommended, therefore, that modifying husbandry practices to avoid outbreaks of luminous vibriosis should be the primary method used to combat this disease in Jasus verreauxi phyllosomas. Different management procedures could include minimising mechanical damage to larvae, controlling the bacterial flora of the culture water through introducing microalgae (Igarashi et al. 1990), use of probiotics (Rengpipat et al. 1998) or immunostimulants (Scholz et al. 1999), and controlling bacteria in live food by using methods such as probiotics, or surface sterilisation (Munro et al. 1999).

Acknowledgements. We thank Toni Wagner for microbiology support. This project was conducted as part of an augmenting PGSF-funded programme CO1606. J. Booth and 2 anonymous referees provided valuable comments on drafts of the manuscript.

\section{LITERATURE CITED}

Anhalt JP, Washington JA (1991) Preparation and storage of antimicrobial solutions. In: Balows A (ed) Manual of clinical microbiology, 5th edn. American Society for Microbiology, Washington DC, p 1199-1200

Austin B, Lee JV (1992) Aeromonadaceae and Vibrionaceae. In: Board RG, Jones D, Skinner FA (eds) Identification methods in applied and environmental microbiology. Society for Applied Bacteriology, Oxford, p 163-182

Baticados MCL, Lavilla-Pitogo CR, Cruz-Lacierda ER, de la Pena LD, Sunaz NA (1990) Studies on the chemical control of luminous bacteria Vibrio harveyi and V. splendidus isolated from diseased Penaeus monodon larvae and rearing water. Dis Aquat Org 9:133-139

Baumann P, Baumann L, Mandel M (1971) Taxonomy of marine bacteria: the genus Beneckea. J Bacteriol 107: 268-294

Beuchat LR (1974) Combined effects of water activity, solute, and temperature on the growth of Vibrio parahaemolyticus. Appl Microbiol 27:1075-1080

Booth JD, Kittaka J (1994) Growout of juvenile spiny lobster. In: Phillips BF, Cobb JS, Kittaka J (eds) Spiny lobster management. Blackwell Scientific Publications, Oxford, p 424-445

Bowser PR, Rosemark R (1981) Mortalities of cultured lobsters, Homarus, associated with a moult death syndrome. Aquaculture 23:11-18

Bryant TN, Smith KR (1991) Bacterial identifier, Version M 1.0. Blackwells, Oxford

Bryant TN, Lee JV, West PA, Colwell RR (1986) A probability matrix for the identification of species of Vibrio and related genera. J Appl Bacteriol 61:469-480

Carson J, Statham P (1993) The inhibition by ionophores invitro of an enterococcal-like pathogen of rainbow trout, Oncorhynchus mykiss. Vet Microbiol 36:253-259

Cawthorne RJ, Lynn DH, Despres B, MacMillan R, Maloney R, Loughlin M, Bayer R (1996) Description of Anophryoides haemophila n. sp. (Scuticociliatida: Orchitophryidae), a pathogen of American lobsters Homarus americanus. Dis Aquat Org 24:143-148

Evans LH, Brock JA (1994) Diseases of spiny lobsters. In: Phillips BF, Cobb JS, Kittaka J (eds) Spiny lobster management. Blackwell Scientific Publications, Oxford, p 461-472 
Fisher WS, Nilson EH, Shleser RA (1975) Effect of the fungus Haliphthoros milfordensis on the juvenile stages of the American lobster Homarus americanus. J Invertebr Pathol 26:41-45

Fisher WS, Nilson EH, Steenbergen JF, Lightner DV (1978) Microbial diseases of cultured lobsters: a review. Aquaculture 14:115-140

Furniss AL, Lee JV, Donovan TJ (1978) The vibrios. Monograph Series 11, Public Health Laboratory Service. Her Majesty's Stationery Office, London

Hooker SM, Jeffs AG, Creese RG, Sivaguru K (1997) Growth of captive Jasus edwardsii (Hutton) (Crustacea: Palinuridae) in north eastern New Zealand. Mar Freshw Res 48:903-909

Igarashi MZ, Kittaka J, Kawahara E (1990) Phyllosoma culture with inoculation of marine bacteria. Nippon Suisan Gakkaishi 56:1781-1786

Illingworth J, Tong LJ, Moss GA, Pickering TD (1997) Upwelling tank for culturing rock lobster (Jasus edwardsii) phyllosomas. Mar Freshw Res 48:911-914

Karunasagar I, Pai R, Malathi GR, Karunasagar I (1994) Mass mortality of Penaeus monodon larvae due to antibiotic resistant Vibrio harveyi infection. Aquaculture 128:203-209

Kittaka J (1994) Larval rearing. In: Phillips BF, Cobb JS, Kittaka J (eds) Spiny lobster management. Blackwell Scientific Publications, Oxford, p 403-423

Kittaka J (1997) Application of ecosystem culture method for complete development of phyllosomas of spiny lobster. Aquaculture 155:319-331

Kittaka J, Ono K, Booth JD (1997) Complete development of the green lobster, Jasus verreauxi from egg to juvenile. Bull Mar Sci 61:57-71

Lavilla-Pitogo CR, Leano EM, Paner MG (1998) Mortalities of pond-cultured juvenile shrimp, Penaeus monodon, associated with dominance of luminescent vibrios in the rearing environment. Aquaculture 164:337-349

Editorial responsibility: Timothy Flegel,

Bangkok, Thailand
Moss GA, Tong LJ, Illingworth J (1999) Effects of light levels and food density on the growth and survival of early stage phyllosoma larvae of the rock lobster Jasus edwardsii. Mar Freshw Res 50:129-134

Munro PD, Henderson RJ, Barbour A, Birbeck TH (1999) Partial decontamination of rotifers with ultraviolet radiation: the effect of changes in the bacterial load and flora of rotifers on mortalities in start feeding turbot. Aquaculture 170:229-244

Pillai D, Jayabalan N (1996) Sensitivity of luminous bacteria Vibrio harveyi to nine selected antibiotics. Indian J Fish 43:399-402

Rengpipat S, Phianphak W, Piyatiratitivorakul S, Menasveta P (1998) Effects of probiotic bacterium on black tiger shrimp Penaeus monodon survival and growth. Aquaculture 167:301-313

Scholz U, Garcia Diaz G, Ricque D, Cruz Suarez LE, Vargas Albores F, Latchford J (1999) Enhancement of vibriosis resistance in juvenile Penaeus vannamei by supplementation of diets with different yeast products. Aquaculture 176:271-283

Sindermann CJ (1990) Principal diseases of marine fish and shellfish, Vol 2. Diseases of marine shellfish, 2nd edn. Academic Press, New York, p 93-144

Stewart JE (1980) Diseases. In: Cobb JS, Phillips BF (eds) The biology and management of lobsters, Vol 1. Academic Press, New York, p 301-342

Stewart JE (1984) Lobster diseases. Helgol Meeresunters 37 : $243-254$

Unestam T (1973) Fungal diseases of Crustacea. Rev Med Vet Mycol 8:1-20

West PA, Colwell RR (1984) Identification and classification of Vibrionaceae-an overview. In: Colwell RR (ed) Vibrios in the environment. John Wiley \& Sons, New York, p 285-363

Submitted: January 17, 2000; Accepted: September 7, 2000 Proofs received from author(s): October 25, 2000 